\author{
Jan Laskowski \\ dr inż. \\ Wyższa Szkoła Przedsiębiorczości i Administracji w Lublinie \\ jlasko@wp.pl
}

DOI: $10.35117 /$ A_ENG_17_11_03

\title{
Evolution of the civil aviation security standards in the European Union
}

\begin{abstract}
Thanks to the rare combination of features most demanded by travelers and freight forwarders, such as speed, security and global reach, air transport has become one of the most promising and profitable branches of the world economy in a very short time. Unfortunately, the dynamic development of air transport has also led to the escalation of completely new, previously unknown threats, such as aviation terrorism. The aim of the article is to present the process of formation of the European Union institutional and legal tools which stand for the protection of civil aviation against acts of terrorism.
\end{abstract}

Keywords: Civil aviation security; Terrorism; European Union Law

Nowadays air transport is a very important part of the global economy, and its condition has a significant impact on the state's finances. The aviation industry generates globally a total of 5.6 million workplaces, and its share in the global economy (direct, indirect, induced, and tourismdriven) is estimated at $\$ 2.2$ trillion ( $€ 1.7$ trillion), what is equivalent to $3.5 \%$ of the world gross domestic product (GDP). Worldwide airlines carry more than 2.6 billion passengers and nearly 48 million tons of cargo annually [1]. In the EU only, the air transport provides 7.8 million workplaces and generates a profit of 475 billion euros, equivalent to $3.9 \%$ of EU gross domestic product (GDP) [2]. Each year in the EU about 780 million passengers and nearly 13 million tons of cargo were transported by the air [12]. The strategic value of aviation for the world economy, coupled with its very high sensitivity to all kinds of interference, creates a straightforward incentive for acts of terrrorism for various terrorist organizations. Since the memorable attacks of $11^{\text {th }}$ September 2001, the international civil aviation security system has been thoroughly rebuilt and refined, but despite this the risk of terrorist attacks on this type of transport is still on a very high level.

\section{The fundamentals of the common EU civil aviation security concept}

One of the cornerstones of the European Union's functioning is the abolition of borders between all the Member States and the creation of a single internal market within them, guaranteeing the free movement of goods, persons, services and capital (Article 26 TFEU) [17]. This principle also applies to the air transport market, which means that any airline registered in any of the Member States can fly anywhere in the EU. The existence of such regulations is a very important for applying to the EU-wide common safety and security standards. This is particularly important in the context of air transport, as the overwhelming majority of air operations are carried out over several national borders. By applying common European standards for the protection of passengers, crews, freight and aircraft and airport infrastructure, we can be sure that the same high standards will be introduced in all the Member States. This also helps to avoid the passenger uncertainty and confusion, which can be generated by the need to comply with many different 
internal security regulations (eg. airport security checks). In addition, the costs associated with the need to comply with many inconsistent standards would be very high for airlines, what can significantly increase prices of a ticket [10]. To sum up, the application by the EU Member States of common security standards improved the comfort and safety of air travel, shortened the predeparture time and, most importantly, lowered the cost of air travel. Generally speaking, these factors increased the availability and popularity of air transportation, which finally stimulates the EU economy.

\section{Development of the EU common civil aviation security standards}

Protecting aviation against various types of unlawful interference has been a matter of intense concern for the international aviation community for several decades. The trigger event that boosted the work of improving the quality of airport security measures was the bombing of Pan Am flight over Lockerbie in 1988, which resulted in the Convention on the Marking of Plastic Explosives for the Purpose of Detection, signed in Montreal on $1^{\text {st }}$ March 1991 [5]. Additionally a special aviation security programme (ICAO AVSEC programme) was launched under the auspices of ICAO [3] and development of new explosive materials detecting technologies was initiated. The threat of aviation terrorism has been evident since the $1960 \mathrm{~s}$, but none of European countries were interested in cooperation aimed to introduce _ common airport security standards. The fight against aviation terrorism was conducted at national level only, accidentally a bilateral cooperation was introduced. The lack of interest of the Member States in the regulation of civil aviation security at a higher pan-European level was caused mainly by unwillingness of particular special services to engage in closer cooperation [10]. The breakthrough occurred after the memorable attacks of $11^{\text {th }}$ September 2001, when the European Council in the Extraordinary Meeting on $21^{\text {st }}$ September 2001 adopted the Conclusions and Action Planon the fight against terrorism[4]. The Council of Transport was obliged to take the necessary measures to improve the protection of air transport within the EU. These activities would include the creation of a list of objects that could be used by terrorists as weapons that should be banned from boarding aircraft, the introduction of technical training for crews, the implementation of procedures for checking and monitoring luggage hatches and access to the cockpit, as well as the quality control of security measures implemented by the Member States. The document also emphasized that the effective and uniform application of the aforementioned measures would be ensured by conducting by the Member States a mutual audits [4]. In the course of the subsequent work on the creation of a unified European aviation security standards, it was stated that all the EU Member States were already signatories to the common aviation security standards developed by European Civil Aviation Conference (ECAC), but none of them fully implemented this regulations [6]. In that situation, the most appropriate was to include these provisions in the framework of the EU legislation, because only this action has ensured their consistent and uniform application by the Member States [10]. Finally, the European Commission, based on ECAC regulations, developed a set of basic civil aviation security standards, which was adopted on $16^{\text {th }}$ December 2002 by the European Parliament as Regulation (EC) No 2320/2002 establishing common rules in the field of civil aviation security [15]. This document obliged all the Member States to develop and implement a "National civil aviation security programme" (Article 5, point 1), designate a single appropriate authority responsible for the coordination and the monitoring of the implementation of this programme (Article 5, point 2), develop and implement within 6 months a national civil aviation security quality control programme(Article 5, point 3 ), to cooperate with Commission officials when they carry out inspections on compliance 
with this Regulation (Article 7 point 3 ) and to establish effective, proportionate and dissuasive penalties for infringement (Article 12). The first and basic implementing document for Regulation No 2320/2002 was Commission Regulation (EC) No 622/2003 of 4 April 2003 laying down measures for the implementation of the common basic standards on aviation security[16]. This document was later amended by dozen mostly confidential updates, which have caused major problems for both travelers and airport managers, because they were obliged to apply regulations to which they had very limited access. An example of such activity was the introduction of a list of prohibited articles, which was included in the secret annex to Regulation No 68/2004[27].

Another significant modification of European civil aviation security standards was made in 2006 following the attempt to bomb by Islamic radicals at least seven airliners flying fromUKto USA (liquid bomb plot). Terrorists planned to use liquid explosives smuggled aboard aircraft in plastic beverage bottles. It should be noted that the plot was averted only by the efforts of the British Special Forces, because the explosives, thanks to innovative construction, were impossible to detect during a routine security check of cabin baggage at the airport. Immediately following these events, the Commission of the European Communities issued Regulation No 1546/2006[20], which supplemented the list of prohibited articles contained in the Annex of Regulation No 622/2003, forbidding all kinds of liquids (except for individual packages of up to $100 \mathrm{ml}$ capacity) [25]. According to the assumptions of legislators, these provisions were to be temporary and in force until a technology of effective detection of liquid explosives was introduced [28].

In 2008, the European Parliament and the Council of the European Union, seeking to simplify, harmonize and making the existing rules more transparent, and to improve the level of civil aviation security, decided to repeal Regulation 2320/2002, together with all its implementing acts, and replace them by provisions which are more appropriate for the new threats. This was done by implementation of Regulation No 300/2008 of 11 March 2008 on common rules in the field of civil aviation security and repealing Regulation No 2320/2002[24], which introduced a series of new measures aimed to improve, streamline and simplify existing procedures, for example by:

- eliminate duplication of security controls, e.g. by limiting costly access controls in the EU airports where screening procedures have already been implemented. This will bring significant benefits to both airlines and airports,

- simplification of procedures, e.g. by establishing a uniform set of standards for the documents required for access to security restricted areas. The new rules clearly specify which types of identification and authorization are needed to grant an individual access to the restricted areas, which will improve the functioning of the airport security system,

- standardization of procedures, e.g. through the introduction of a common procedure for the safety certification of carriers carrying air cargoes across the EU. These certificates will be recognized in all the Member States, which will reduce the need for costly multiple security checks, and

- introduction of common minimum safety standards such as, for example, uniform training for all employees who participate in security control process [11].

The effective implementation of the provisions contained in Regulation No 300/2008 also required the amendment of the whole package of complementary and implementing regulations, the most important of which was the Commission Regulation (EC) No 272/2009 of 2 April 2009 
supplementing the common basic standards on civil aviation security laid down in the Annex to Regulation (EC) No 300/2008 of the European Parliament and of the Council[23], and its basic implementing document, Regulation No 185/2010 of 4 March 2010 laying down detailed measures for the implementation of the common basic standards on aviation security [22].

Another incident that resulted in the modification of European civil aviation security procedures was carried out on $25^{\text {th }}$ December 2009 by Nigerian al Qaeda supporter Umar Farouk Abdulmutallab, attempting to blow up a passenger plane flying from Amsterdam to Detroit (underwear bomb plot). The bomber was able to bypass the enhanced Schiphol airport security system by the use of a new, innovative solution, which was sewing of powdered explosives into personal underwear. Fortunately, despite the attempted detonation, this bomb from unexplained reasons did not explode[29]. This incident was the main argument that convinced the European Parliament to allow the introduction of body scanners at the EU airports. Despite of many doubts accompanying the work on the implementation of this new solution, including its impact on privacy and passenger health [9], finally amendments to Regulations 272/2009 and 185/2010 introducing detailed guidance on how to use the body scanners at the EU airports were adopted in November 2011 [26].

Considering the evolution of the concept of civil aviation security in the EU, we cannot forget about a very important aviation transport sector that is the cargo. Recent events have shown that terrorists, due to the strengthening of passenger security procedures, have begun to be interested in the less protected segment of air transport, which are cargo and mail. An example of this is the attempt to blow up two UPS cargo aircraft in $29^{\text {th }}$ October 2010 (air cargo bomb plot). In both cases, 300-400 grams of explosives and detonation mechanisms were mounted into printer toners, which were then packed and shipped by air mail from Yemen to the United States. These attacks were thwarted only by operational information obtained and transferred to the CIA by the Saudi Special Service, which allowed to locate and neutralize the bombs during the stopovers at the airports of East Midlands Airport (UK) and Dubai (United Arab Emirates) [7]. This incident revealed another weak point in the civil aviation security system and showed that the EU regulations on the protection of air cargo and mail had to be corrected immediately. Therefore, in November 2010, the European Commission has developed an Action Plan to strengthen air cargo protection [8], where a newholistic air cargo protection model was proposed. This document assumed the implementation of new uniform European control standards consisting of air cargo and mail coming from non-EU countries to the EU airports, the establishment of an information exchange system providing information about new threats, incidents and rescue actions, and intensification of activities in the ICAO forum aimed to completion of Annex 17 on issues related to the protection of air cargo[8]. New regulations concerning securityof air cargo and mail brought to the EU airports from third countries were introduced on $1^{\text {st }}$ February 2012 by the Commission Implementing Regulation (EU) No 859/2011 of 25 August 2011 on amending Regulation (EU) No 185/2010 laying down detailed measures for the implementation of the common basic standards on aviation security in respect of air cargo and mail[19], which implements, inter alia, procedures for approval of air carriers, as so-called. ACC3 (air cargo carrier or airmail operator operating from a third country airport to the Union). ACC $3 \mathrm{~s}$ must ensure that all cargo and mail is physically screened according to the EU standards or comes from the EU aviation security validated secure supply chain. The EU aviation security validation of ACC3's cargo and mail operations at each departure airport for the EU bound flights is mandatory since $1^{\text {st }}$ July 2014.The EU ACC3 programme, implemented by the Commission Implementing Regulation (EU) No 2015/1998 laying down detailed measures for the 
implementation of common basic standards on aviation security[18] does not apply to cargo and mail operations from origins with robust aviation security measures and with an established low risk, as identified through the EU Risk Assessment. At the same time, additional rules apply to cargo and mail that has been identified, again through the EU Risk Assessment, as high riskcargo and mail. The details of these risk-based measures are communicated to air carriers by the appropriate authorities of the EU Member States.

Summarizing the above analyses, it should be noted that the EU legislation on civil aviation security against terrorism, as well as general anti-terrorism legislation, have emerged in a response to the emergence of more or less spectacular acts of aviation terrorism (Figure 1). Despite the reluctance of the EU Member States to introduce more and more stringent standards, a comprehensive set of common rules on civil aviation security has finally been developed and introduced. Significantly, these regulations, thanks to successive modifications, work in practice, as evidenced by the fact that all civil aviation terrorist attacks conducted in the European Union have failed (they have been thwarted in the organization or implementation phase).

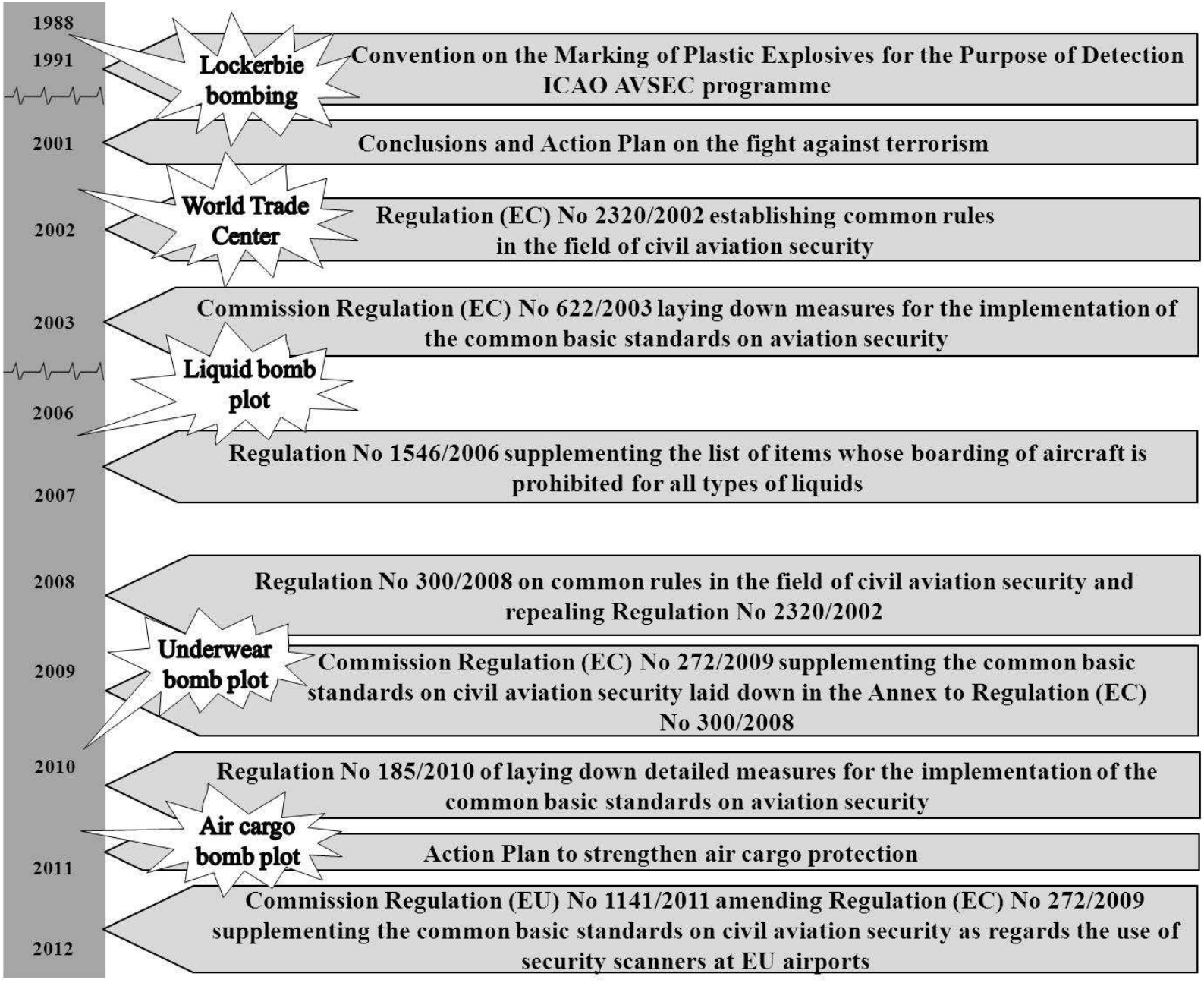

1. Legal provisions on civil aviation security adopted by the EU in response to acts of terrorism 


\section{Source materials}

[1] Air Transport Action Group (ATAG), Aviation: benefits beyond borders, report, 2012, p. 24, http://aviationbenefitsbeyondborders.org/download-abbb-report, 12.09.2013.

[2] Air Transport Action Group (ATAG), Aviation: benefits beyond borders. European Union 27 nations, report, 2012, p. 2-3. http://aviationbenefitsbeyondborders.org/sites/aviationbenefitsbeyondborders.org/files/pdfs/ ABBB_EU_summary_Oct2012_web.pdf, 12.09.2013.

[3] Antonini D.R., Facilitation: The ultimate security solution?, ICAO MRTD report, vol. 5, no $1 / 2010$, p. 33.

[4] Council of European Union, Conclusions and Plan of Action of The Extraordinary European Council Meeting on 21 September 2001, Brussel, 21 September 2001, http://www.consilium.europa.eu/uedocs/cms_data/docs/pressdata/en/ec/140.en.pdf, 05.04 .2013 .

[5] Dz. U. z $2007 \mathrm{nr} 135$ poz. 948.

[6] ECAC, ECAC Policy Statement in the Field of Civil Aviation Facilitation, Doc No. 30. https://www.ecac-ceac.org//publications_events_news/ecac_documents/ecac_docs, 23.09.2013.

[7] EU Terrorism Situation and Trend Report TE-SAT 2011, Hague 2011, p. 15. https://www.europol.europa.eu/latest_publications/29, 02.04.2012.

[8] European Commission, A European action plan to strengthen air cargo security, $\mathrm{IP} / 10 / 1651, \quad 02.12 .2010, \quad \mathrm{http}: / /$ europa.eu/rapid/press-release_IP-10-1651_en.htm, 30.09.2013.

[9] European Commission, Communication from the Commission to the European Parliament and the Council on the Use of Security Scanners at EU airports, COM(2010) 311 final, Brussels, 15.06.2010.

[10] European Commission, Flying safely in Europe. EU aviation safety and security policy, Luxembourg 2005, p. 1.

[11] European Commission, Transport: EU updates aviation security rules to simplify and improve procedures, 29.04.2010, http://europa.eu/rapid/press-release_IP-10-479_en.htm, 25.09.2013.

[12] Eurostat, Air

transport, http://epp.eurostat.ec.europa.eu/portal/page/portal/transport/data/main_tables, 09.09.2013.

[13] Implementing Regulation No 1147 / 2011 amending Regulation (EU) No 185/2010 laying down detailed measures for the implementation of the common basic standards on aviation security with respect to the use of scanners at EU airports (Official Journal of the European Union, L 294, 12 November 2011).

[14] Official Journal of the European Communities, L 10, 16 January 2004.

[15] Official Journal of the European Communities, L 355, 30 December 2002.

[16] Official Journal of the European Communities, L 89, 5 April 2003.

[17] Official Journal of the European Union, C 326, 26 October 2012, p. 59.

[18] Official Journal of the European Union, L 122, 13 May 2017.

[19] Official Journal of the European Union, L 220, 26 August 2011.

[20] Official Journal of the European Union, L 286, 17 October 2006.

[21] Official Journal of the European Union, L 324, 22 November 2012.

[22] Official Journal of the European Union, L 55 z 5 March 2010.

[23] Official Journal of the European Union, L 91 z 3 April 2009. 
[24] Official Journal of the European Union, L 97, 9 April 2008.

[25] Paszkiewicz O., System ochrony lotnictwa cywilnego i zagrożenie terrorystyczne po 2001 roku, ,Terroryzm”, no 1/2008, p. 25.

[26] Regulation (EC) No 1141/2011 amending Regulation (EC) No 272/2009 supplementing the common basic standards on civil aviation security with respect to the use of scanners in EU airports (Official Journal of the European Union, L 293 of 11 November 2011).

[27] Ross T., EU aviation security: drowning in red tape, 22.11.2012, $\mathrm{http}$ ://airportfocusinternational.com/eu-aviation-security-drowning-in-red-tape-extendedversion, 24.09.2013.

[28] Thomas M., The EU regulatory framework applicable to civil aviation security, European Union, 2013, p. 11.

[29] United States District Court, Indictment in U.P. v. Abdulmutallab, http://www.cbsnewp.com/htdocs/pdf/Abdulmutallab_Indictment.pdf, 30.05.2012. 